\title{
Practical Recommendations on the Organization of Pedagogical Monitoring in Institutions of Vocational Education
}

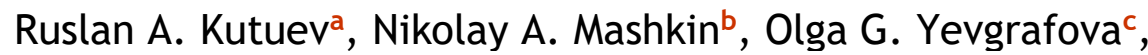 \\ Alexander V. Morozov ${ }^{d}$, Anna N. Zakharova ${ }^{e}$ and Viktor T. Parkhaev ${ }^{f}$
}

${ }^{a}$ Chechen State University, RUSSIA; bPlekhanov Russian University of Economics, RUSSIA;

'Kazan (Volga region) Federal University, Kazan, RUSSIA; dUlyanovsk State Agricultural Academy named after P. A. Stolypin, RUSSIA; ${ }^{e}$ Chuvash State University, RUSSIA; Humanities Institute of Television and Radio Broadcasting Named after M. A. Litovchin, RUSSIA.

ABSTRACT

The relevance of the study is conditioned by the need to adapt vocational training to the needs of a modern economy. The purpose of the paper is to develop practical guidance on the pedagogical monitoring in vocational education institutions. The leading approach to the study is the processinformation approach, which allows considering monitoring as a specially organized continuous process of search and comprehensive analysis of indicators in order to promptly diagnose and forecast the state of the educational system, taking into account the goals. The study involves 500 teachers, 500 students who have defined the criteria for effective implementation of the regional component of vocational education. The main results of the study are to identify the objects and the main directions of pedagogical monitoring in vocational education institutions. The significance of the results obtained is that the revealed pedagogical monitoring facilities allow to track the results of vocational training on the planned, implemented and achieved stages, provide teachers, heads of vocational training institutions with objective and timely information necessary for making decisions on managing and making adjustments to the trust, organizational, informational, regulatory parameters of the organization of vocational training. Elucidated pedagogical monitoring trends cause systemic-structural integrity and content-methodical continuity at all stages of vocational education

KEYWORDS

Pedagogical monitoring, the organization of vocational training, the regional component of vocational education
ARTICLE HISTORY

Received 11 September 2016

Revised 10 November 2016 Accepted 22 December 2016

\section{CORRESPONDENCE R. A. Kutuev $\square$ kra-07@mail.ru}

\section{(C) 2017 R. A. Kutuevet al.}

Open Access terms of the Creative Commons Attribution 4.0 International License apply. The license permits unrestricted use, distribution, and reproduction in any medium, on the condition that users give exact credit to the original author(s) and the source, provide a link to the Creative Commons license, and indicate if they made any changes. (http://creativecommons.org/licenses/by/4.0/) 


\section{Introduction}

The relevance of the study is reasoned by the need to adapt vocational training to the needs of a modern economy. A characteristic feature of the modern world development is the transition of the leading countries to build an economy based mainly on the generation, distribution and use of knowledge. The most important factor in improving the economic performance of society is the human potential, especially its creative, research competences (Pugacheva et al., 2016a; Drovnikov et al., 2016). In this regard, the training of creative professionals is emphasized. Substantial changes in the system of vocational education and its adaptation to the needs of a modern economy are required. Currently, there are various forms of social partnership in the system of vocational education, the integration of vocational education institutions is enhanced and public-social forms of control are introduced (Lunev et al., 2016; Erdyneeva et al., 2016). In these conditions a special significance is belonged particularly to the quality of management activities, without increasing of which it is impossible to solve theoretical and practical tasks of the vocational education system. One of the effective ways to achieve the objectives is monitoring, allowing analyzing, diagnosing, adjusting and predicting the trends of development of vocational education system at the national, regional, municipal and local levels (Burkova, 2006). Currently, there is no unity in the approach to building monitoring vocational training. It has been established that the concept "monitoring" is transformed from a more general ("the checking and recording of students' knowledge", "monitoring of students' achievements"), the quantitative ("assessment of knowledge and skills"), to the more hard ("control and accounting of knowledge and skills" "measuring the level of achievement by students of the educational standard") (Polonsky, 2000; Kuprina, 1999; Majorov, 2005). Analysis of the frequency in the use of certain concepts allows monitoring to identify common characteristics: process, system, watching, analysis, forecasting, and diagnostics of the state of the object or process, examination. The subject of monitoring is a pedagogical system that unites students, teachers, objectives, content, forms, methods and means of education. The main objectives of pedagogical monitoring is an assessment of the knowledge, abilities and skills, competencies (in the broader sense - academic achievements) and their correlation with a given level of standard (standard) or statistical norms (Podlasiy, 2003). Comprehensive information provided by the pedagogical monitoring, enhances the level of interaction between the different actors of the educational process, and creates the conditions for self-esteem and self-identity, self-education and self-development for these participants (Niyazova, 2008). Monitoring of institutions of vocational education is a specially organized continuous process of teams' search and a comprehensive analysis of indicators in order promptly to diagnose and forecast the state of the educational system in accordance with the intended impacts, objectives, development of correctional and preventive actions of management. The aim of the paper is to develop practical guidance on the pedagogical monitoring in vocational education institutions.

\section{Research methodology}

The leading approach to the study is the process-information approach, which allows considering monitoring as a specially organized continuous process of search and comprehensive analysis of indicators in order to diagnose and forecast promptly the state of the educational system, taking into account the goals. The monitoring covers all structures of vocational education institutions, including individual monitoring of students, and performs management, evaluation (qualimetric), supervisory-control and information function. On the basis of these functions, professional education process can be built accordingly, taking into account all relevant 
information received in the course of monitoring. Thus, monitoring is a complex phenomenon that is interdisciplinary in nature. Monitoring can be considered as informational, diagnostic, prognostic process carried out in the framework of the management activities. The dictionary of V.M. Polonsky (2000) defines monitoring as a long-term monitoring of the state of training and education and the management of these processes by timely informing the participants about the possible occurrence of adverse, critical or harmful situations.

Based on a process-informational approach, we have defined the principles of research: 1) the principle of consistency - monitoring, consistent with the aims and nature of the processes studied on the basis of one-time, periodic, regular or random observations of the object, the subjects of the educational system and their relationships (Lunev, Pugacheva \& Stukolova, 2014a); 2) scientific principle - relying on analysis of strict scientific data, which are amenable to empirical testing and identification, and can be confirmed or refuted by other researchers (Lunev, Pugachova, Stukolova, 2014b); 3) the principle of objectivity, including the selection of data that objectively exist and do not contradict each other (the same results received by different groups of observers in assessing the level of specialists' readiness for professional activity) (Terentyeva et al., 2016b); 4) the principle of integrity, including checking of indicators, complex characteristics of which gives a complete picture of the object as a whole, and not just about its individual parts (Pugacheva et al., 2016c); 5) the principle of efficiency, requiring information for management decision-making in the required time, and not at the moment when the changes cannot be adjusted (Akhmetov et al., 2016); 6) The principle of adequacy, involving selection of the measurement procedures, which are adequate to monitoring goals and objectives, as well as the opportunities and ethical standards (Ivanov et al., 2016). During the research the following methods were used: theoretical (analysis, synthesis, generalization and systematization); sociological (observation, interviews, questionnaires).

\section{Results}

The main results of this study are: 1) objects of pedagogical monitoring; 2) basic trends of pedagogical monitoring in vocational training institutions; 3 ) monitoring of the implementation of the regional component of vocational education.

\section{Objects of pedagogical monitoring}

It is found that the objects of pedagogical monitoring in the institutions of vocational education can be: the characteristic of the institution, the qualitative composition of applicants, the quality of specialists' training, demand for graduates in the regional market of labor, qualification of teaching staff, the content of vocational education, protection and strengthening of students' health, information-methodical and material -technical support.

Characteristics of vocational education institutions includes: rating in the system of regional institutions of vocational education; rating in the national system of institutions of vocational education of similar profile; contingent and the quality of education of applicants (by specialties); contingent, and the number of undergraduates and their distribution by specialties, forms of education; students' movement (elimination and migration).

The qualitative composition of applicants is characterized by an analysis of the results of education; sociological survey aimed at identifying the students' motivation to obtain professional education; social and material status of the enrolled applicants 
(the number of enrolled applicants from low-income, single-parent families, applicants - orphans and the disabled).

The quality of specialists' training involves analysis: of the results of current progress, control testing during the interim and final certification; State exam results; results of protection of final qualifying works; the results of a sociological survey on the quality of graduates' training; the quality of the examination results of graduates' training; the results of teachers' sociological survey on the quality of graduates' training.

The demand for graduates in the regional labor market is related to the analysis of: graduates' employment outcomes for three, six months and one year after graduation; graduates' appeals to the employment service; reviews of employers about the quality of graduates' training.

Qualifications of teaching staff takes into consideration the following factors: the number of teachers with a degree; work experience in an educational institution; age structure of teachers.

The content of vocational training should be reflected in the curricula, educational programs on specialties.

Questions on protection and strengthening of students' health include: taking into account of students' medical examination; the number of days missed by students due to illness; the number of students who study on individual forms of learning; attendance by students of sports clubs in the institution and outside it.

Information and methodical support is characterized by the following indicators: the availability of the students' textbooks, taking into account of the number of students visiting the library; to what extent encyclopedic, educational, methodical literature and periodicals are used by the students; level of students' provision with computers; publishing activity in the educational institution. Material and technical support involves equipping of classrooms and laboratories, libraries, sports facilities (gyms, swimming pools, a center of health care and physical therapy); providing students with a dormitory, food, medical care, state, nominal and social grants.

Effective organization of monitoring on the level of vocational education institution is associated with the definition of goals and objectives, selection of best monitoring tools. Improving the efficiency of vocational training on the basis of monitoring is a process of phased tracking of key learning outcomes in the planned, implemented and achieved stages.

Monitoring at the planning stage involves an assessment of curricula on the specialties, program-methodical maintenance and educational content. Monitoring at the implementation level allows comprehensively assessing the level of students' readiness to vocational activity. Monitoring at the achievement stage makes it possible to compare the goals planned and implemented, to make appropriate corrective changes in the organization of vocational training.

\section{Basic trends of pedagogical monitoring in vocational education institutions}

It is found that the pedagogical monitoring will be effective tool in quality management of vocational training in case of providing focus on the analysis of the organization of the educational process, students' development conditions, continuous professional training of teaching staff for the timely management of decision-making (Yepaneshnikov et al., 2016). The main pedagogical monitoring trends in vocational training institutions are defined, which are presented in Table 1. 
Table 1. Basic pedagogical monitoring directions in the institution of vocational training

\begin{tabular}{|c|c|c|}
\hline Direction & Task & The result \\
\hline $\begin{array}{l}\text { socio - economic } \\
\text { planning of staff } \\
\text { training in the } \\
\text { regional conditions }\end{array}$ & $\begin{array}{l}\text { to identify future needs of the region in } \\
\text { specialists; to predict the introduction of new } \\
\text { promising specialties; to predict the role and } \\
\text { functions of educational institution in } \\
\text { providing of educational services to the } \\
\text { population; to identify future needs for } \\
\text { retraining and staff's continuous professional } \\
\text { development of the regions. }\end{array}$ & $\begin{array}{l}\text { creating tools to study } \\
\text { future needs of the } \\
\text { region in staff and } \\
\text { educational services. }\end{array}$ \\
\hline $\begin{array}{l}\text { personal-oriented } \\
\text { model of } \\
\text { education }\end{array}$ & $\begin{array}{l}\text { to identify and characterize the individual } \\
\text { trajectories of students' training; to } \\
\text { determine their goals, objectives, } \\
\text { functions; to create the variable } \\
\text { educational curricula and programs in } \\
\text { relation to different trajectories of } \\
\text { students' training; to develop a system of } \\
\text { monitoring the quality of training. }\end{array}$ & $\begin{array}{l}\text { practical } \\
\text { recommendations on } \\
\text { the organization of } \\
\text { individual trajectories } \\
\text { of students' training }\end{array}$ \\
\hline $\begin{array}{l}\text { the content of } \\
\text { vocational } \\
\text { education }\end{array}$ & $\begin{array}{l}\text { to study the content of vocational } \\
\text { education; to determine the principles of } \\
\text { selection and structuring the content of } \\
\text { educational curricula, programs and their } \\
\text { compliance with the requirements of state } \\
\text { standard }\end{array}$ & $\begin{array}{l}\text { practical } \\
\text { recommendations for } \\
\text { the improvement of } \\
\text { curricula and programs. }\end{array}$ \\
\hline $\begin{array}{l}\text { forms and methods } \\
\text { of vocational } \\
\text { education }\end{array}$ & $\begin{array}{l}\text { to identify traditional and innovative forms } \\
\text { and methods of vocational education, to } \\
\text { find out their similarities and differences. }\end{array}$ & $\begin{array}{l}\text { practical } \\
\text { recommendations for } \\
\text { the implementation of } \\
\text { traditional and } \\
\text { innovative forms and } \\
\text { methods of vocational } \\
\text { education. }\end{array}$ \\
\hline $\begin{array}{l}\text { the content and } \\
\text { organization of } \\
\text { independent work } \\
\text { of students }\end{array}$ & $\begin{array}{l}\text { to summarize the experience of } \\
\text { organization of students' independent } \\
\text { work; to identify the ratio of classroom } \\
\text { and independent work of students; to } \\
\text { develop mechanisms of organization of } \\
\text { students' independent work }\end{array}$ & $\begin{array}{l}\text { practical } \\
\text { recommendations for } \\
\text { teachers on the } \\
\text { organization of } \\
\text { independent work of } \\
\text { students. } \\
\text { Practical advice for } \\
\text { students on } \\
\text { independent work. }\end{array}$ \\
\hline $\begin{array}{l}\text { organization and } \\
\text { content of } \\
\text { industrial training } \\
\text { (vocational } \\
\text { practice). }\end{array}$ & $\begin{array}{l}\text { to determine an effective balance } \\
\text { between theoretical and practical training } \\
\text { of students at different stages of } \\
\text { vocational education; to define the } \\
\text { objectives, content of industrial } \\
\text { (vocational practice) training; to identify } \\
\text { the effectiveness of various types of } \\
\text { industrial (professional practices) training. }\end{array}$ & $\begin{array}{l}\text { practical } \\
\text { recommendations for } \\
\text { organization of } \\
\text { industrial (professional } \\
\text { practices) training. }\end{array}$ \\
\hline $\begin{array}{l}\text { monitoring the } \\
\text { quality of } \\
\text { vocational } \\
\text { education of } \\
\text { students at }\end{array}$ & $\begin{array}{l}\text { to substantiate the indicators of the } \\
\text { quality of vocational education of students } \\
\text { at different stages; to determine the types } \\
\text { and forms of monitoring the quality of } \\
\text { vocational education in different stages; to }\end{array}$ & $\begin{array}{l}\text { practical } \\
\text { recommendations on } \\
\text { organization of } \\
\text { monitoring the quality } \\
\text { of vocational education }\end{array}$ \\
\hline
\end{tabular}




\begin{tabular}{|c|c|c|}
\hline different stages. & $\begin{array}{l}\text { develop a system of tasks for diagnosis and } \\
\text { correction of quality of students' } \\
\text { vocational education. }\end{array}$ & at different stages. \\
\hline $\begin{array}{l}\text { the management } \\
\text { system of the } \\
\text { education process. }\end{array}$ & $\begin{array}{l}\text { to justify the principles, functions, criteria } \\
\text { and types of management of educational } \\
\text { process, the program of teachers' } \\
\text { continuous professional education. }\end{array}$ & $\begin{array}{l}\text { the program of } \\
\text { management of } \\
\text { educational process. } \\
\text { The program of } \\
\text { teachers' continuous } \\
\text { professional education. }\end{array}$ \\
\hline $\begin{array}{l}\text { development of } \\
\text { information and } \\
\text { technology base }\end{array}$ & $\begin{array}{l}\text { to identify the state of information and } \\
\text { technology base }\end{array}$ & $\begin{array}{l}\text { development of the } \\
\text { plan of information and } \\
\text { technology base }\end{array}$ \\
\hline $\begin{array}{l}\text { improving the } \\
\text { system of } \\
\text { planning, } \\
\text { organization and } \\
\text { management of } \\
\text { the training and } \\
\text { educational } \\
\text { process in } \\
\text { vocational } \\
\text { institution. }\end{array}$ & $\begin{array}{l}\text { to develop system of selection and support } \\
\text { of gifted students; to justify and to build a } \\
\text { hierarchy of directions of development of } \\
\text { the institution. }\end{array}$ & $\begin{array}{l}\text { practical } \\
\text { recommendations for } \\
\text { the development of the } \\
\text { institution. }\end{array}$ \\
\hline
\end{tabular}

Table 1 shows that the implementation of the main directions of pedagogical monitoring in the institution of vocational training will allow carrying out the systemicstructural integrity and content-methodical continuity at all stages of vocational education; will contribute to the preservation, promotion and continuous professional development of teaching staff, the stability of the teaching staff; increase the efficiency of students' socialization (Petrova et al., 2016).

\section{Monitoring of the implementation of the regional component of vocational education}

Under the regional component of vocational education is understood the pedagogical interpretation of socio-economic and cultural status of the regional community (Pugacheva et al., 2016b). We have identified the following components in the content of a regional component: 1) methodical - a reflection of a regional component in teaching and curricular documentation; 2) reflexive - the adjustment of the regional component on the basis of analysis and generalization of the results of its experimental testing. The content of a regional component of vocational education defines: 1) the interest of all sectors of economic and socio-cultural complex in highly qualified specialists of the profile, which is necessary not only now, but also will be desired in the future (Terentyeva et al., 2016a); 2) the natural competition of workers to make demands to the real skill which is reflected in the professional knowledge, skills and competences; 3 ) competition of professional education institutions (Lunev et al., 2016).; 4) the creation of new specialties, with the help of which young people can gain a strong and worthy future (Pugacheva et al., 2016a); 5) effective youth policies aimed at the inclusion of young professionals in the market relations on the basis of education obtained (Zamaletdinov et al., 2016); 6) vocational training methods (Kamasheva et al., 2016). During the survey of 500 teachers, 500 students from vocational education institutions of the Republic of Tatarstan, Kazan Russia, the efficiency realization criteria of a regional component of vocational education were defined: student satisfaction with the educational process; ensuring the unity and 
continuity of vocational training and retraining, their continuous professional development; reducing migration of specialists at the expense of retraining and continuous professional training at working place, taking into account the specifics of the region, the social and cultural situation in the region. Organization of monitoring in the implementation of the regional component of vocational education on the basis of identified criteria allowed: 1) ensure the sustainable operation and development of vocational education institutions; 2 ) to reduce the pressure on the labor market, make more efficient the use of human resources, to ensure uniform requirements for the training of specialists in the region; 3) update the content of vocational education; 4) to ensure employment of graduates.

\section{Discussions}

Issues of pedagogical monitoring is devoted a lot of research. The regional aspect of the application of monitoring is particularly fully represented in the works of S.N Pishchulin (1998), M.A. Dombrovskaya (2000). Researchers on the basis of monitoring carry out analysis of the quality of education in regional institutions of vocational education in conditions of a market economy; give an objective assessment of the regional system of vocational training and identify the prospects of its development in the coming years. Several studies have shown the use of monitoring as a means of improving the management system of vocational education at different levels throughout the country, region, or individual institution. These are the works of S.E. Shishov \& V.A. Kal'ney (1998), R.T. Farkhutdinov (1998), A.I. Shchetinskaya (1998) D.Sh. Matros, D.M. Polev \& N.N. Mel'nikova (1999), A.I. Kuprina (1999), S.V. Shvetsova (2000), N.L. Gunyavina (2000) A.N. Majorov (2005). In the works of these authors: 1) the importance of monitoring is emphasized as a means of quality control of vocational training if there is a possibility to identify possible correction and preventive measures of administrative influence, taking into account the results obtained; 2) it is notes that the creation of a system of educational statistics and monitoring model of the quality of education are two different tasks, each of which has its own specificity; 3) various types of monitoring are scientifically justified, which can be classified on several bases (scope, data collection tools, measuring instruments).

Analysis of the works of these authors shows that among experts there is no consensus about the nature of pedagogical monitoring. The differences lie in the interpretation of goals and objectives, objects, types of pedagogical monitoring. Objectives of pedagogical monitoring are very different. This is a collection, compilation and preliminary analysis of information on the state of education and its main indicators of its use to assess and predict trends in development, make informed management decisions. The objectives of monitoring are: the organization of observations and measurements; obtaining of reliable and objective information about the conditions of conducting, the content and results of the educational process; the development and application of standardized regulations, methods of diagnosis, procedures of their use; systematization and testing of information, conducting of monitoring studies at all levels; development of software and hardware of monitoring, etc.

Monitoring objects are also extremely varied. These are educational institutions, educational authorities, structural elements and components of the educational systems of different levels, the processes of formation and development, educational content, learning objectives, curricula, plans, techniques, tools, and others. The subject of monitoring is the specific changes in the state of the education system in certain periods of time. It is necessary to emphasize the importance of analyzing not only the individual quantitative and qualitative indicators of the educational system, but also the 
changes resulting from comparisons. Monitoring tools are statistical reporting forms, questionnaires, checklists, various tasks and techniques. Strictly monitoring is a set of procedures for the collection, processing, presentation and dissemination of information, organization and provision of appropriate monitoring procedures.

Classification of types of monitoring is quite diverse. There are regulated statistical monitoring based on the data of statistical reporting, as well as non-statistical monitoring based on independently developed by researchers indicators and private diagnostic methods and procedures of measurement. Statistical or non-statistical monitoring is used depending on management objectives. For the purposes of education is very important to identify the peculiarities of statistical monitoring. Thus the key issue is the justification and selection of specific indicators for diagnosis and monitoring. The requirements for monitoring should be clear and simple, the results obtained should be objective, reliable, easily understood, have immediate relation to the essence of the process. Depending on the breadth and scope of the monitoring facilities there can be Federal, regional, municipal and institutional system of education. Monitoring can be done by different methods depending on the nature of investigated objects, their direct or indirect measurement. Monitoring can be considered in a different plane, depending on its orientation to a specific user (students, parents, employers, and the public). In this case, its purpose may be, for example, the formation of public opinion, characteristics of the education system at the regional level, and the results are intended mainly for managers.

The diversity of opinions of researchers about the nature of pedagogical monitoring makes it difficult for its use in educational practice. It actualized the purpose of our study.

\section{Conclusion and Recommendations}

Managing vocational education, increase its efficiency and quality implies a deliberate and systematic monitoring of the activities of vocational education institutions. In this regard, to obtain versatile analytical information pedagogical monitoring is important. Monitoring involves continuous tracking and observation of the object of administrative activity, analysis of its condition by measuring and comparison of actual results with predetermined goals, forecasting changes in the state of the object with the aim of making management decisions aimed at improving the quality of the object. The results of the study allow making the following practical recommendations on the organization of pedagogical monitoring in institutions of vocational education.

First. The fundamental differences of pedagogical monitoring from the traditional methods of measurement of the educational process consists in the fact that its results do not passively register the actual situation, but actively influence on the further development of educational institutions, the creative potential of the teaching staff, increasing of the level of its professional competence.

Second. Objects of pedagogical monitoring are associated with its sources (statistics; sociological research; materials of evaluation and accreditation reports of institutions of vocational education; reports of the chairmen of state attestation commissions on specialties; the results of final state certification of graduates on specialties of vocational education; results of competitions, Olympiads for students; materials of evaluation of the teaching staff; the results of testing of applicants and students of educational institutions).

Third. The main directions of pedagogical monitoring involve such methods as a method of comparative evaluation (comparison with standards of quality of 
professional education); expertise (internal and external); surveys of students, parents, representatives of enterprises, institutions, organizations associated with the assessment of the quality of specialists' training. Means of evaluating results of the monitoring are: tests to assess the knowledge of students and graduates; and evaluation tools that simulate practical activities of graduates of educational institutions; sociological tools.

Fourth. Monitoring of regional components of vocational education allows making the process structurally complete; promotes the conservation, development and continuous professional training of the teaching staff, and also stimulates innovative activity of teachers in vocational education.

The results of the study allow us to outline the prospects for further research of the problems associated with the diagnosis of the educational space of educational institutions of different types and kinds in the system of vocational education. The paper submissions may be useful for leaders and teachers of vocational education institutions; employees of the centers of continuous professional training and retraining of personnel in the selection and structuring the contents of continuous professional training of the teaching staff from institutions of vocational education.

\section{Disclosure statement}

No potential conflict of interest was reported by the authors.

\section{Notes on contributors}

Ruslan A. Kutuev - PhD, Associate Professor, Vice-Rector for Science and Innovation, Chechen State University, Grozny, Russia.

Nikolay A. Mashkin - PhD, Professor of the Department of "State-legal disciplines", Plekhanov Russian University of Economics, Moscow, Russia.

Olga G. Yevgrafova - PhD, Associate Professor of the Department of Foreign Languages, Kazan (Volga region) Federal University, Kazan, Russia.

Alexander V. Morozov-PhD, Associate Professor of the Department of Materials and Mechanical Engineering Technology, Ulyanovsk State Agricultural Academy named after P. A. Stolypin, Ulyanovsk, Russia.

Anna N. Zakharova - PhD, Associate Professor of the Department of Social and Clinical Psychology, Chuvash State University, Cheboksary, Russia.

Viktor T. Parkhaev - PhD, Professor of the Department of TV and Film Cameramen Shooting Skills, Humanities Institute of Television and Radio Broadcasting Named after M. A. Litovchin, Moscow, Russia.

\section{References}

Akhmetov, L.G., Khramova, N.A., Sychenkova, A.V., Chudnovskiy, A.D., Pugacheva, N.B., Pavlushin, A.A., Varlamova, M.V. \& Khilsher, V.A. (2016). Selective Support for the Development of Regional Vocational Education Services: the Russian Experience. International Review of Management and Marketing, 6(2), 127-134.

Burkova, N.G. (2006). Monitoring in the institution of secondary vocational education, the World of education. The education in the world, 4,53-61.

Drovnikov, A.S., Nikolaev, E.L., Afanasev, A.S., Ivanov, V.N., Petrova, T.N., Tenyukova, G.G., Maksimova, N.L. \& Povshednaya, F.V. (2016). Teachers Professional Competence Assessment Technology In Qualification Improvement Process. International Review of Management and Marketing, 6(1), 111-115.

Erdyneeva, K.G., Nikolaev, E.L., Azanova, A.A., Nurullina, G.N., Bogdanova, V.I., Shaikhlislamov, A.K., Lebedeva, I.V., \& Khairullina, E.R. (2016). Upgrading Educational Quality through Synergy of Teaching and Research. International Review of Management and Marketing, 6(1), 106-110.

Farkhutdinov, R. T. (1998). Improvement of management activities to address social problems of young people on the basis of monitoring: $\mathrm{PhD}$ thesis. Ufa: Bashkir state University. 
Gunyavina, N.L. (2000). Scientific-methodical principles of monitoring of the implementation of the state educational standard of secondary vocational education (on the example of pedagogical specialties): PhD thesis. Moscow: research Institute of higher education.

Ivanov, V.G., Barabanova, S.V., Shagieva, R.V., Chikisheva, N.M., Lunev, A.N., Volkova, N.V., Nabiullina, K.R. \& Spirina, E.V. (2016). The Essence and Content of State Regulation of Services Development in Conditions of Increasing Autonomy of Federal State Entities. International Review of Management and Marketing, 6(2), 149-154

Kamasheva, Y.L., Goloshumova, G.S., Goloshumov, A.Y., Kashina, S.G., Pugacheva, N.B., Bolshakova, Z.M., Tulkibaeva, N.N. \& Timirov, F.F. (2016). Features of vocational education management in the region. International Review of Management and Marketing, 6(1), 155-159.

Kuprina, A. I. (1999). Monitoring as a means of improving the quality of management of educational process: PhD Thesis. Ekaterinburg: Ural state pedagogical University.

Lunev, A.N., Pugacheva, N.B. \& Stukolova, L.Z. (2014a). Development strategies for professional educational services under the increasing autonomy of territories within the federal state. Actual Problems of Economics, 160(1), 215-220.

Lunev, A.N., Pugachova, N.B. \& Stukolova, L.Z. (2014б). Socially oriented regional economic space as an instrument in managing the development of service sector. Actual Problems of Economics, 155(5), 247250.

Lunev, A.N., Safin, R.S., Korchagin, E.A., Sharafutdinov, D.K., Suchkova, T.V., Kurzaeva, L.V., Nikishina, S.R. \& Kuznetsova, N.A. (2016). The Mechanism of Industrial Educational Clusters Creation as Managerial Entities of Vocational Education. International Review of Management and Marketing, 6(2), 166-171.

Majorov, A.N. (2005). Monitoring in education. Moscow: Intellect-Center.

Matros, D.S., Polev, D.M. \& Mel'nikova, N.N. (1999). Quality management of education on the basis of new information technologies and education monitoring. Moscow: Pedagogical society of Russia.

Niyazova, M.V. (2008). Functions of the University as a socially responsible institution. Problems of modern Economics. Direct access: http://www.m-economy.ru/art.php?nArtId=1942 (date accessed: 02.11.2016).

Petrova, T.N., Kirillova, O.V., Sokolova, S.G., Pugacheva, N.B., Galimullina, A.F., Maksimova, O.G., Antonova, T.V. \& Kozhanov, V.V. (2016). Education as the Management of Research Universities Students' Socialization. International Review of Management and Marketing, 6(2), 28-33.

Pishchulin, S. N. (1998). Marketing monitoring of the education system: PhD thesis. Moscow: Moscow state University named after M. V. Lomonosov.

Podlasiy, I.P. (2003). Pedagogy. Book 2: The process of education. Moscow: Gumanit. ed. center VLADOS

Polonsky, V.M. (2000). Dictionary of concepts and terms for education and pedagogy. Moscow: Miros, 368 p.

Pugacheva, A.S., Filippova, V.P., Kon, A.Y., Dorzhieva, L.B., Silchenok, I.S., Pugacheva, N.B., Lunev, A.N. \& Mustafina, A.A. (2016a). Market Regulators of Service Spheres Innovative Development as a Tool of Regional Socio-Economic Policy. International Review of Management and Marketing, 6(2), 294-300.

Pugacheva, N.B., Kirillova, T.V., Ovchinnikova, I.G., Kudyashev, N.K., Lunev, A.N., Pavlova, O.A., Kashina, S.G. \& Valeyev, A.S. (2016b). The Mechanism of State-Public Management of Vocational Education in the Region. International Review of Management and Marketing, 6(2), 6-11.

Pugacheva, N.B., Ezhov, S.G., Kozhanov, I.V., Kozhanova, M.B., Ogorodnikova, S.V., Oshaev, A.G., Timonin, A.I. \& Goloshumova, G.S. (2016c). The model of self-realization readiness formation of research universities students in the process of civic education. International Review of Management and Marketing, 6, 128133.

Shchetinskaya, A. I. (1998). Theory and practice of development of creative potential of a teacher in terms of monitoring the quality of additional education of children: $\mathrm{PhD}$ thesis. Kazan: Kazan State University.

Shishov, S. E. \& Kal'ney, V.A. (1998). Monitoring the quality of education at school. Moscow: Pedagogical society of Russia.

Shvetsova, S. V. (2000). Socio-psychological monitoring as a tool for improving governance in education: $\mathrm{PhD}$ thesis. Yaroslavl: Yaroslavl state University named after P. G. Demidov.

Terentyeva, I.V., Mukhomorova, I.V., Perezhogina, O.N., Pugacheva, N.B., Lunev, A.N., Akhmetzyanova, G.N., Lezhnin, V.V. \& Gainullina, R.R. (2016a). Development Strategy of Service Sector in Conditions of Federal States Entities Autonomy Increasing. International Review of Management and Marketing, 6, 15.

Terentyeva, I.V., Starodubtsev, M.P., Timonin, A.I., Pugacheva, N.B., Zykova, N.N., Lunev, A.N., Ezhov, S.G. \& Starikova, L.D. (2016b). Assessment of state services quality and availability in the socio-cultural sphere. International Review of Management and Marketing, 6, 122-127. 
Yepaneshnikov, V.V., Pugacheva, N.B., Goloshumova, G.S., Kuznetsova, V.V., Dobrovolskaya, L.V., Moiseeva, L.V., Garaganov, A.V. \& Litvinenko, N.A. (2016). Pedagogical Management of Civil Education of Research Universities Students. International Review of Management and Marketing, 6(2), 23-27.

Zamaletdinov R.R., Yudina N.P., Lavrentyeva E.I., Savva L.I., Pugacheva N.B. (2016). Practical Recommendations on the Improvement of the Effectiveness of Anti-Corruption Policy in Universities. International Review of Management and Marketing, 6(2), 390-396. 